\title{
natureoUTLOOK LYSOSOMAL STORAGE DISORDERS
}

22 September 2016 / Vol 537 / Issue No 7621

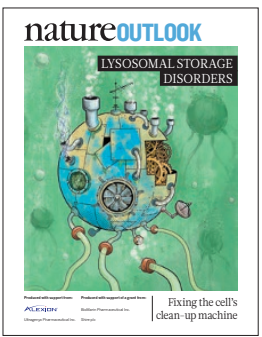

Cover art: Nik Spencer

\section{Editorial}

Herb Brody, Michelle

Grayson, Nick Haines, Richard Hodson,

Jenny Rooke

Art \& Design

Mohamed Ashour,

Andrea Duffy,

Wesley Fernandes,

Denis Mallet, Wojtek

Urbanek

Production

Matthew Carey, Ian

Pope, Karl Smart

Sponsorship

Janice Stevenson,

Samantha Morley

Marketing

Nicole Jackson

Project Manager

Anastasia Panoutsou

Art Director

Kelly Buckheit Krause

Publisher

Richard Hughes

Editorial Director,

Partnership Media

Stephen Pincock

Editor-in-Chief

Philip Campbell
$\mathrm{T}$ hey can come on slowly in adulthood or arrive suddenly and fatally in infancy. Their symptoms can include seizures and dementia, enlargement of the spleen and liver, and abnormal bone formation. They are rare, yet vary in frequency: the most common occur once in every 50,000 or so live births, but the rarest have been seen barely a handful of times. Indeed, at first glance, there is seemingly little to connect the 50 or so lysosomal storage disorders (LSDs), except that they all involve the lysosome (S146).

What a piece of work is a lysosome! For decades, it was thought to be just a recycling organelle - the cell's rubbish bin for disposing of unwanted cellular debris. But now it is clear that the lysosome is not only dynamic but also vital to the health of the cell (S148). Lysosomal dysfunction is implicated in other common diseases, with LSDs providing a window into the underlying cellular processes (S160).

So far, only ten LSDs have drug therapies (others are amenable to bone-marrow transplants), but LSDs with neurological dysfunction - which is most of them - are particularly poorly served. Changing this with either drugs (S154) or gene therapy (S158) is a major challenge.

Much of the support for LSD research is led by foundations set up by the parents of a child with one of the disorders (S152). Many such organizations push for the screening of newborns to identify LSDs early. Although this would seem to be a good idea, such initiatives are fraught with ethical difficulties (S162). But early detection is crucial if a person with an LSD is to have any chance of living a normal life (S151).

We are pleased to acknowledge financial support from Alexion Pharmaceuticals, Inc. and Ultragenyx Pharmaceutical Inc., and grants from Shire plc and BioMarin Pharmaceutical Inc. As always, Nature retains sole responsibility for all editorial content.

\section{Michelle Grayson}

Senior supplements editor

\section{CONTENTS}

\section{S146 CELL BIOLOGY}

Myriad maladies

What goes wrong to cause an LSD?

S148 BIOMEDICINE

A rare opportunity

The lysosome has a role in many

diseases

S151 PERSPECTIVE

The rare must become common

Marc C. Patterson calls for more

screening to aid diagnosis

\section{S152 ADVOCACY}

Strong foundations

How parent power can aid the

development of drugs for rare diseases

\section{S154 DRUG DEVELOPMENT}

Through the barrier

Treatments need to get to the brain

\section{S158 GENE THERAPY}

A new chapter

Delivering a second treatment

revolution

S160PERSPECTIVE

Finding common ground

Anthony $\mathrm{H}$. Futerman and John Hardy

seek to tie together two diseases

\section{S162SCREENING}

Baby's first test

It is time for a rethink on screening newborns

S165 RESEARCH

4 big questions

Directions for future research

\section{RELATED ARTICLES}

Nature Outlooks are sponsored supplements that aim to stimulate interest and debate around a subject of interest to the sponsor, while satisfying the editorial values of Nature and our readers' expectations. The boundaries of sponsor involvement are clearly delineated in the Nature Outlook Editorial guidelines available at go.nature.com/e4dwzw

CITING THE OUTLOOK

Cite as a supplement to Nature, for example, Nature Vol. XXX, No. XXXX Suppl., Sxx-Sxx (2016).

VISIT THE OUTLOOK ONLINE

The Nature Outlook Lysosomal Storage Disorders supplement can be found at http://www.nature.com/nature/outlook/lysosomal-storagedisorders It features all newly commissioned content as well as a

selection of relevant previously published material.

All featured articles will be freely available for 6 months SUBSCRIPTIONS AND CUSTOMER SERVICES Site licences (www.nature.com/libraries/site_licences): Americas, institutions@natureny.com; Asia-Pacific, http://nature.asia/ jp-contact; Australia/New Zealand, nature@macmillan.com.au; Europe/ROW, institutions@nature.com; India,npgindia@nature. com. Personal subscriptions: UK/Europe/ROW, subscriptions@ nature.com; USA/Canada/Latin America, subscriptions@ us.nature.com; Japan, http://nature.asia/jp-contact; China, http:// nature.asia/china-subscribe; Korea, www.natureasia.com/ko-kr/ subscribe.

CUSTOMER SERVICES

Feedback@nature.com

Copyright $\odot 2016$ Macmillan Publishers Ltd. All rights reserved.
S166 Sphingolipid disorders

Frances M. Platt

S174 Enzyme enhancers for the treatment of Fabry and Pompe disease Jan Lukas et al.

S183 Pompe disease in adulthood: effects of antibody formation on enzyme replacement therapy Juna M. de Vries et al. 